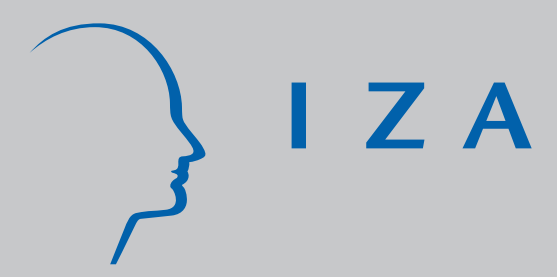

IZA DP No. 5882

Surviving the Crisis:

Foreign Multinationals vs Domestic Firms in Ireland

Olivier Godart

Holger Görg

Aoife Hanley

July 2011

Forschungsinstitut

zur Zukunft der Arbeit

Institute for the Study

of Labor 


\title{
Surviving the Crisis: Foreign Multinationals vs Domestic Firms in Ireland
}

\author{
Olivier Godart \\ Kiel Institute for the World Economy \\ Holger Görg \\ Kiel Institute for the World Economy \\ and IZA \\ Aoife Hanley \\ Kiel Institute for the World Economy
}

Discussion Paper No. 5882

July 2011

IZA

P.O. Box 7240

53072 Bonn

Germany

Phone: +49-228-3894-0

Fax: +49-228-3894-180

E-mail: iza@iza.org

\begin{abstract}
Any opinions expressed here are those of the author(s) and not those of IZA. Research published in this series may include views on policy, but the institute itself takes no institutional policy positions.

The Institute for the Study of Labor (IZA) in Bonn is a local and virtual international research center and a place of communication between science, politics and business. IZA is an independent nonprofit organization supported by Deutsche Post Foundation. The center is associated with the University of Bonn and offers a stimulating research environment through its international network, workshops and conferences, data service, project support, research visits and doctoral program. IZA engages in (i) original and internationally competitive research in all fields of labor economics, (ii) development of policy concepts, and (iii) dissemination of research results and concepts to the interested public.
\end{abstract}

IZA Discussion Papers often represent preliminary work and are circulated to encourage discussion. Citation of such a paper should account for its provisional character. A revised version may be available directly from the author. 
IZA Discussion Paper No. 5882

July 2011

\section{ABSTRACT}

\section{Surviving the Crisis: Foreign Multinationals vs Domestic Firms in Ireland *}

Starting from the observation that all firms in Ireland (foreign and domestic in manufacturing and services industries) were hit by the crisis, the paper asks whether there is a difference in the behaviour of foreign and domestic firms. One hypothesis is that foreign multinationals are less linked into the Irish economy, so more likely to leave once the economy is hit by a negative shock. The paper discusses background hypotheses before giving empirical evidence from firstly aggregate data, and secondly firm-level observations. The analysis of the latter suggests that foreign firms are not more likely to leave during the crisis than Irish firms. Some policy conclusions are offered in the paper.

JEL Classification: F3, J2, L2

Keywords: financial crisis, firm survival, Ireland

Corresponding author:

Holger Görg

Kiel Institute for the World Economy

Hindenburgufer 66

D-24105 Kiel

Germany

E-mail: holger.goerg@ifw-kiel.de

\footnotetext{
* We are very grateful to Kevin Phelan of the Central Statistics Office for his unstinting help with the CIP data and to participants at the Lehigh conference and a seminar at the Kiel Institute for very helpful comments. We gratefully acknowledge financial support through the European Commission, as part of the SERVICEGAP Project (Grant Agreement no. 244 552).
} 


\section{INTRODUCTION}

Ireland's precipitous economic decline has become a bye-word for political and banking mismanagement. Even at the time of writing, there are new reports of fresh cash injections to support a foundering banking system. Such injections have severe implications for Ireland's international credit rating and borrowing requirements. However, what market-insiders, and increasingly the media, realise is that the productive sector activities of firms in manufacturing and services -show some signs of resilience.

Brian Devine, economist at Davy Stockbrokers is reported in a BBC dispatch as saying that; "If it weren't for the exporting sector the economy would be in far worse shape." ${ }^{1}$ The Irish manufacturing sector is largely driven by exports which according to Davy Stockbrokers are expected to grow by a further 6 percent in 2011 despite a 1.6 drop in Irish GDP in the final quarter of 2010.

Among exports, those from the service sector are also burgeoning and generating revenues close to those of manufacturing sector exports. According to the chief economist at National Irish Bank, Ronnie O’Toole, the growth in the services sector represents "the big success story in the economy over the last decade” with services exports in 2009 totalling €70bn compared to a value of €80bn for exports of physical outputs (FDI Intelligence, 2010). O’Toole ascribes this service sector export growth to a shift from low value-added manufacturing activities to better quality services jobs.

A large share of productive activity and exports in both manufacturing and services is generated by foreign multinationals located in Ireland. Indeed, the need to maintain Ireland as an attractive venue for foreign direct investment (FDI), thereby avoiding a large drop in exports, is one reason for the increasingly vocal battle to maintain Ireland's highly competitive corporation tax rate vis-à-vis other EU member states.

\footnotetext{
${ }^{1}$ See http://www.bbc.co.uk/news/business-12931167, accessed on 16/5/2011
} 
In view of the importance of foreign multinationals in any revival of the Irish economy, this paper aims to document the short-run impacts of the global financial crisis on the Irish productive sector, distinguishing foreign multinationals and domestic firms, from its inception in 2008.

A report on the response of foreign-owned firms during the crisis, showed aboveaverage job shedding of foreign owned firms in Ireland compared to their peers in other world economies (42 percent job losses between 2008 and 2009 compared with a global average of 25 percent) (FDI Intelligence, 2010). The same report showed Ireland slipping two places in the World Investment Index from 21 to 23 in a selection of some of the world's largest 30 economies. ${ }^{2}$ However, this report does not interpret these employment shocks in the context of other factors. Most importantly, it does not compare the performance of foreign multinationals with that of domestic firms and neglects the fact that FDI is especially dominant in high-tech industries.

Accordingly, existing accounts as to how firms have responded to the crisis in Ireland invariably raise more questions than they solve due to the need for a systematic study of the crisis when controlling for other firm- and industry-level characteristics. This is the gap our paper aims to fill. Specifically, we look in detail at the incidence of firm closures during the crisis. Is there any sign that foreign multinationals are quick to leave the Irish economy during this time of crisis, thereby introducing more instability into the economy? Or do they actually act as stabilizers during this economic downturn?

Our analysis asks whether certain types of firms, namely those that are foreignowned are better able to withstand the shock of a serious recession. To do this we firstly describe some manufacturing-wide patterns of firm exit, employment and output changes in recent years using the latest available aggregate data from the Central Statistics Office. We

\footnotetext{
${ }^{2}$ The Inward Investment Index calculates the attractiveness of a country as a destination for FDI in terms of job creation, the number of investment projects which were successfully awarded and the amount of money invested.
} 
then dig deeper and analyse the exit of firms using firm-level data from the Amadeus database to estimate hazard functions. ${ }^{3}$ We look at the period 2006 - 2009 to scrutinize the impact of the crisis for all firms both in the manufacturing and service sectors.

We find a number of important results. Firstly, unsurprisingly, the likelihood of firm survival decreased unambiguously during the crisis in both the manufacturing and the services sector. Our estimations suggest that, on average, a manufacturing firm is 40 percent more likely to exit during the crisis than before. This increase is even higher for services firms at 80 percent. At the heart of our paper is the question whether these exit probabilities are different for foreign and domestic firms. For the manufacturing sector, the answer is a simple "no". In the services sector, however, we do find an intriguing result in a comparison of firms from EU countries and Irish owned firms. While European firms are about 40 percent less likely than Irish firms to exit before the crisis, this advantage evaporates completely during the crisis, when there is no difference between the two groups of firms. Services firms from the US or other non-European countries are at no time different in their exit behaviour than Irish firms.

We discuss some background to motivate our empirical analysis in the next section. Section 3 then presents a first stab at the empirical analysis, presenting an aggregate picture using industry level data for manufacturing sectors from the Central Statistics Office. Section 4 then turns to the micro level, analysing firm-level data for the Irish manufacturing and services sectors. Section 5 presents some policy implications of our empirical analysis.

\section{BACKGROUND}

This analysis follows on from an earlier pre-crisis analysis looking at differences in survival for foreign and domestic Irish firms based on plant level data from the Forfás

\footnotetext{
${ }^{3}$ We thus, in that section of the paper, look at the extensive margin of firm adjustment in terms of firm exit. A related question would be to see what happened to the intensive margin, i.e., employment growth in surviving firms. Unfortunately, however, even the data for 2008 and 2009 still contain too many missing values for employment and, hence, a meaningful analysis is not yet possible.
} 
Employment Survey from 1973 to 1996 (Görg and Strobl, 2003). This paper finds that, when looking at the raw data, foreign multinationals appear more likely to exit a market than domestic firms. However, this can be explained by the fact that multinationals are on average larger firms, and are concentrated in high tech industries. Once controlling for these firm and industry characteristics, the study shows that multinationals are actually less likely to leave, thereby introducing stability into the economy.

Our paper is also related to an early study by McAleese and Counahan (1979). They analysed whether foreign multinationals in Ireland reduced employment during the early 1970s recession to a larger extent than indigenous plants, i.e., whether multinationals were faster to adjust employment levels following an adverse shock than were Irish-owned plants. Their evidence showed that employment adjustments in multinational corporations (MNCs) during the recession did not appear to have been different from that of indigenous plants, while employment recovery after the recession was actually greater in MNCs than in Irish-owned plants. However, they do not relate this finding to greater survival probability in multinational than in domestic firms.

There are a number of reasons why we may expect some differences between foreign affiliates and domestic firms in their exit behaviour during the crisis. One argument emphasises the notion of multinationals being more footloose, i.e., more likely to leave an economy than domestic firms if the economy experiences a negative shock (e.g, Görg and Strobl, 2003). This may be due to multinationals being part of an international production network in which production can be easily shifted between locations, and where they are less linked into the local host country economy. This argument is backed by two empirical observations.

Firstly, multinationals generally do less of their input sourcing in the host country than domestic firms. This implies that they are less linked into the local input market. For the Irish case, Görg and Ruane (2000) and Barry and Bradley (1997) both find that 
multinationals have lower linkages with upstream firms, i.e., their ratio of domestically sourced to total inputs is lower than for domestic firms. Specifically, Barry and Bradley (1997) find for the Irish manufacturing sector in 1993 that foreign multinationals source on average 34 percent of their material inputs in Ireland, while this ratio is 79 percent on average for domestic firms. ${ }^{4}$ Görg and Ruane (2000) distinguish the sourcing of materials and services inputs using data for the Irish electronics industry. They find that in 1995, multinationals source 23 percent of their materials and 72 percent of their services in Ireland, compared with 32 and 89 percent, respectively, for domestic firms.

The second observation that relates multinationals to footloose behaviour is the importance of the local market for firms' output. Here it appears that multinationals are generally more export intensive. Hence, they are less linked into the local output market. For example, Barry and Bradley (1997) show using data for 1993 that the average domestic firm exports 39 percent of its total output, while this export ratio is 85 percent for foreign multinationals. This picture becomes even starker when contrasting EU multinationals and US multinationals: the former have an export ratio of 62, the latter of 96 percent.

While these arguments suggest that multinationals may be more likely to leave the host country, a contrary reasoning can also be advanced. One may argue that foreign affiliates are less likely to exit because investing abroad involves substantial unrecoverable investment costs, also called sunk costs, which are likely to be higher than for setting up a purely domestic plant in the host country. Hence, they may be reluctant to leave if the shock is only temporary. If sunk costs are indeed important, then one would expect these firms to be more productive. The reasoning for this is that only the most productive firms may be able to bear the additional sunk costs of investing abroad, as suggested by Helpman et al. (2004). It is well established in the literature that foreign firms are more productive

\footnotetext{
${ }^{4}$ The finding that multinationals have lower linkages than domestic firms is mirrored in studies for other countries, see, for example, Alfaro and Rodriguez-Clare (2004) for Costa Rica, or Driffield and Mohd Noor (1999) for Malaysia.
} 
than domestic firms. Ruane and Ugur (2005) illustrate this using Irish firm-level data for the manufacturing sector. While, as usual, the labour productivity measurement in Ireland should be taken with a pinch of salt due to the practice of transfer pricing, it is reassuring to note that a large international literature also finds that foreign multinationals are more productive than domestic firms (e.g., Girma and Görg, 2007 for the UK, Doms and Jensen, 1998 for the US).

To sum up, the expectation as to the behaviour of foreign firms is ambiguous. One can plausibly argue that they may be more footloose and more likely to leave the Irish economy during the crisis, although one may equally sensibly also argue the opposite. Hence, we need to turn to empirical evidence to investigate this further.

\section{THE AGGREGATE PICTURE}

We firstly look at some aggregate data to get an idea of the broad picture on firm exit and related jobs in Ireland. The Census of Industrial Production compiled by the Central Statistics Office provides unique information on the whole spectrum of firms in manufacturing industries and includes unique information on domestic and foreign owned firms for different aggregates. The most recent available years are 2008 and 2009. Table 1 depicts the main information concerning the number of firms, employees and output by nationality of firms.

Although the number of foreign owned firms appears to have dropped by 16 percent, from 506 to 424 units, in the lead up to the crisis, the number of foreign firms is less severely affected than the number of Irish-owned firms. The latter experienced a drop of 13 percent. However, this difference remains marginal. Furthermore, these changes need 
to be interpreted carefully. The reason is that the surveying techniques employed by the official statistics have switched from local units to enterprises between 2008 and $2009 .^{5}$

(Table 1 here: Changes in Irish Manufacturing (2008-2009))

Employment figures (which are not influenced by the survey technique) show a similar steep decrease in domestic and foreign firms (-11 percent and -10 percent respectively) which keeps the share of employees in foreign entities stable at a 47 percent level. ${ }^{6}$ This shows the importance of foreign multinationals for employment in Ireland. In contrast, output values show a different short term pattern. While output of domestic firms has nearly stagnated, output of foreign firms has increased from 2008 to 2009 by 10 percent. As a consequence, higher labour productivity growth is observed when measured by output per employee. Thus, in the time of the crisis the decline in employment was accompanied by a productivity surge. ${ }^{7}$

To get a more accurate picture of the impact of the global financial crisis we now consider the composition of industry. Unfortunately, this is only possible up to $2007 .{ }^{8}$ FDI in Ireland exhibits strong sectoral patterns with foreign-owned activities heavily concentrated in high tech industries (Ruane and Görg, 1997). Hence, a slump in global demand may affect foreign-owned firms differently depending on the extent to which the shock is sector specific.

Table 2 illustrates this strong sectoral bias of foreign-owned firms towards the hightech end of the economy with 19, 11 and 29 percent of their activity (measured in terms of employment) concentrated in the high-tech sectors chemicals including pharamaceuticals, (NACE 24), computers (NACE 30) and telecommunication equipment (NACE 32-33),

\footnotetext{
${ }^{5}$ An enterprise might include several local units, thus the numbers in the table might over-report the extent of exit

${ }^{6}$ This is comparable with the share reported by Görg and Strobl (2003) for 1995, when foreign-owned firms also accounted for about 47 percent of total manufacturing employment.

${ }^{7}$ Note however, that output numbers and thus productivity should be interpreted with care for multinationals. As multinationals often rely on international transfer pricing, the output numbers artificially over-estimate the real production of multinationals in Ireland (e.g. Barry, 2005).

${ }^{8} 2007$ is the last year when it is possible to make these calculations. The official statistics post-2007 no longer differentiate between foreign-owned and Irish employment on the basis of these classifications.
} 
respectively in 2007. The corresponding values for Irish firms are 1 and 3 percent respectively. By contrast, Irish owned firms tend to be more concentrated in the more traditional food (NACE 15) and metals (NACE 27-28) sectors.

(Table 2 here: Manufacturing employment by two digit sector, 2000 and 2007)

To sum up, several patterns from the data emerge from our examination of aggregate statistics. Firm numbers and employment in both foreign and Irish firms in the manufacturing industry have dropped during the crisis. Sales for both Irish and foreign firms have been reasonably steady, and are still heavily dominated by foreign firms due to the prevalence of transfer pricing. Due to the nexus between falling employment in the context of steady or rising sales, labour productivity has been rising. This rise in labour productivity especially characterizes foreign owned multinationals. Another well-known feature of foreign presence in Ireland is the dominance of these firms in high value added and economically relevant high tech sectors such as computers, pharmaceuticals and medical instrumentation.

\section{THE MICRO LEVEL PICTURE}

While looking at aggregate data deserves attention and provides a snapshot of sectoral responses to the global financial crisis, the data we use thus far focus only on the manufacturing sector. Furthermore, aggregate changes are unable to reveal which factors drive firm-level survival. Only recently, some studies have overcome this drawback and documented how firm-level factors such as the multinational status, employment size at the firm's inception, age and the industry classification of activities have a statistical effect on the probability of failure (e.g., Görg and Strobl, 2003, Agarwal and Audretsch, 2001, Dunne and Hughes, 1994).

Although the crisis in Ireland triggered by global demand shocks affected all firms operating in Ireland, theory and empirical evidence tell us that the crisis may have affected 
firms unequally. The literature on firm survival posits that larger and older, established firms are less likely to close down (e.g., Dunne and Hughes, 1994). Also, the level of technology used in a sector plays a role in shaping survival probabilities (Agarwal and Audretsch, 2001). These stylized facts from existing work may favour the survival prospects of foreign firms, as these are generally larger than domestic firms, and part of established, technologically advanced multinationals (Ruane and Görg, 1997). However, irrespective of these characteristics, there may also be a 'multinationality effect' particular to these firms. As discussed in Section 2, foreign multinationals, by virtue of their imbeddedness into global production and sales networks and their ability to reallocate their activities internationally might be expected to behave differently when faced with a demand shock than their Irish counterparts.

In order to see whether we find support for these hypotheses, we examine the determinants of survival rates of foreign and domestic firms in Ireland during the crisis, using very recent firm-level panel data in the next section.

\section{a. Data and descriptive statistics}

The firm-level data set we use is the Amadeus database, a commercial dataset provided by Bureau van Dijk. It contains extensive firm-level information on European firms. We access the database for Ireland. ${ }^{9}$ Amadeus provides detailed yearly information on the activities of each firm, its profit and loss accounts, balance of payment information and ownership structure. In the case of Ireland it enables us to identify numerous variables that we use in our study: foreign ownership, legal date of any cessation of activity and some additional variables such as employment, the age of the firm and the 4-digit (NACE Rev. 1.1) industries. Furthermore, as this dataset includes also services sector firms, it provides a

\footnotetext{
${ }^{9}$ In Ireland, Private (Ltd) limited companies are required to file accounts with the Irish Companies Registry . This information is gathered by Bureau van Dijk. In general, the Amadeus sample includes only firms that have an operating revenue greater than 1 million EUR, or total assets greater than 2 million EUR, or more than 150 employees.
} 
richer picture of the Irish economy than a study that would be based solely on the manufacturing sector.

From the ownership section of the data we are able to construct a foreign ownership indicator for a firm. A firm is considered to be foreign if it is majority owned, wholly owned or the main known shareholder is foreign. In a sense, this variable states that a foreign firm is entitled to control or to manage the Irish located affiliate as it has the largest ownership share.

Firm exit is defined as the termination of a firm's activities. Information about this is provided by a 'legal status' variable in the Amadeus dataset. It indicates whether a firm is active or inactive. Inactive firms are defined as firms that are in liquidation, dissolved or in receivership. In order to identify with accuracy the timing of any legal cessation of a firm's activity, we complement this Amadeus variable with information from the Irish Company Registration Office (CRO) databank. The CRO databank provides among other things the precise date of cessation of activity of a firm located in Ireland and allows a researcher to pinpoint in which year the inactive firm in the Amadeus dataset stopped trading. ${ }^{10}$ Hence, these two datasets together allow us to track in detail whether or when a firm stopped being active and whether or not it was foreign owned.

Our data set comprises information for 22,428 domestic and 1,727 foreign firms in 2005 in the manufacturing and commercial services sector (excluding public services, NGOs and private households). We analyze these data over the period 2006 to 2009 in order to focus on the short run impact of the financial crisis.

Tables 3 and 4 show the evolution of failure for domestic and multinational firms from 2006 until 2009. ${ }^{11}$ The absolute number of exits shown in Table 3 is, of course,

\footnotetext{
${ }^{10}$ To be precise, we use mainly the time series on legal status of firms provided in Amadeus. Nevertheless around 500 firms have been double-checked in the CRO databank. We found that some firms that are classified as inactive in Amadeus are actually active. This was then corrected in our data.

${ }^{11}$ Although available, we do not use data for 2010 as there are a large number of missing values in the data and we can therefore not say with any confidence whether a non-response in the data is due to a true exit.
} 
higher among Irish owned firms. However, looking at the fractions of failures (exit rates) in Table 4 shows that these appear reasonably similar, with annual failure rates of between 1 and 4 percent.

(Table 3 here: Summary statistics: Firm-level Data )

(Table 4 here: Irish and Foreign Firm Exit Rates)

It is also apparent from Table 4 that failure rates increase substantially from the start of the crisis in 2008. This is true for both foreign and Irish owned firms. The year 2008 also shows the only significantly marked difference in failure rates between Irish and multinational firms. The failure rates of Irish firms peak at 3.4 percent compared to the lower value of 2.32 for foreign multinationals and the statistical significance of this difference is attested by the accompanying test statistic (Pearson’s Chi-Square).

Overall however, there seems little evidence to distinguish the exit rates for Irish and foreign firms. Although the survival rates of foreign firms appear marginally better, turning our attention to a survival regression framework will help to establish whether what we can see in the descriptive statistics (marginally higher survival of multinationals in Ireland) is also observable when controlling for other important features of the firm such as age, size and sector.

\section{b. Econometric analysis}

In our data we can only observe firm exit on a yearly basis. This feature of the data necessitates the use of discrete-time survival models. A widely used model in this case is the complementary log-log model, which allows us to model the hazard of firm exit. ${ }^{12}$ In proportional hazard models, the hazard rate $\theta(\mathrm{t}, \mathrm{X})$ satisfies an important separability assumption, $\theta(t, X)=\theta_{0}(t) \exp \left(\beta^{\prime} X\right)$, thus it is the product of a baseline hazard $\theta_{0}(t)$,

\footnotetext{
12 The complementary log-log model is the discrete time version of the proportional hazard models. See Jenkins (2005) for an excellent overview of complementary log-log and proportional hazard models.
} 
which depends only on time at risk, and $\exp \left(\beta^{\prime} X\right)$ which is independent of $t$ and depends on the attributes of the firm ( $\mathrm{X}$ ), such as ownership, size and age.

The appropriate discrete-time hazard function, $\mathrm{h}(\mathrm{j}, \mathrm{X})$ shows the interval hazard for the $\mathrm{j}^{\text {th }}$ time interval, i.e. the period between the beginning and the end of the $\mathrm{j}^{\text {th }}$ year after the firm first appears in the sample (with left censoring). This hazard rate takes the following form:

$$
h(j, X)=1-\exp \left[-\exp \left(\beta^{\prime} X+\gamma_{j}\right)\right]
$$

where $h(t, X)$ is the hazard rate, i.e., the probability that the firm exits in period $t$ given that it had not exited before that period. Our main interest lies in the identification of the $\beta$ parameters, which shows the effect of the explanatory variables on the hazard rate. Positive estimates suggest that larger values of the explanatory variables increase the hazard of firm exit, or equivalently, decrease the probability of firm survival. A negative coefficient estimate suggests that the variable is negatively associated with the hazard and, hence, positively affects survival. ${ }^{13}$

Our hazard model includes the following variables in the vector X. Firstly, we include employment size, firm age and two digit industry dummies, as suggested by the literature on firm survival cited above. ${ }^{14}$ Secondly, we include an indicator variable that is equal to one if a firm is foreign-owned, and zero if it is Irish owned. Thirdly, as our time period includes years before and during the crisis, we have generated a binomial 'crisis variable' that is equal to one for the years during the crisis and zero before the crisis. Finally, to check whether foreign firms react differently than domestic firms during the

\footnotetext{
${ }^{13}$ The $\gamma_{\mathrm{j}}$ parameters represent the differences in values of the integrated hazard function for different durations. While it is possible to impose some restrictions on these parameters, we see no reason for this. Thus we estimate a full set of $\gamma_{j}$ s, transforming the model to a type of semi-parametric one in this respect.

${ }^{14}$ Employment size is measured as average employment in a firm between 2005 and 2009. Firm age is its age in 2005.
} 
crisis, we also include an interaction term of the foreign-ownership variable and the crisis variable.

We, firstly, estimate our model using data for all firms collectively in order to establish a benchmark result. ${ }^{15}$ The results are presented in Table 5 and include two sets of results, which differ in the timing of the crisis variable only. There is no clear guidance as to when exactly the global crisis began, when it hit Ireland, or how long the delay was before affecting different firms in the real economy. Generally speaking, September 2008, or more specifically the collapse of Lehman Brothers seems to be regarded as the start of the crisis, while the Irish bank bailout started making headlines from December 2008 onwards. Given this ambiguity about the exact timing of the crisis, and the availability only of yearly observations, we use two definitions of the crisis variable: one starting in 2008 and the other in 2009.

\section{(Table 5 here: Firm exit, all firms)}

The coefficients in Table 5 depict the relationship between the explanatory variables and the hazard of firm exit. One can see that firm size and firm age are negatively and statistically significantly correlated with firm exit. This is what one would expect from the literature: larger and older, more established firms are less likely to exit. While we do not report the coefficients on the sectoral dummies in the table, their inclusion in the specification allows us to interpret the coefficients of the other variables abstracting from sector-specific characteristics.

We find that firm exit becomes more likely during the crisis from the positive coefficient on the crisis dummy. The foreign ownership dummy returns a negative coefficient, implying that foreign firms in general are less likely to exit than domestic firms, irrespective of the effect of the crisis. This mirrors earlier findings by Görg and Strobl (2003) for Irish manufacturing. The interaction of (foreign * crisis) returns a positive

\footnotetext{
${ }^{15}$ The survival analysis is implemented using the cloglog commands in Stata Version 10.
} 
coefficient. A test of the hypothesis that the coefficient on the foreign dummy and the interaction of (foreign * crisis) add up to zero indicates that we cannot reject this hypothesis. ${ }^{16}$ Hence, the advantage of foreign firms in terms of lower exit probabilities evaporates during the crisis.

In other words: foreign firms per se are more likely to stay in the economy than comparable domestic firms when the economy is running smoothly. However, during the crisis, multinationals are no different in terms of their exit probabilities compared to their domestic counterparts. That is, when the economy turns sour, multinationals are just as likely to leave as are domestic firms.

Before we attempt to put some actual numbers on the difference in exit hazards between foreign and domestic firms, we turn to look at some possible sources of heterogeneity in our sample. We first distinguish firm survival in manufacturing and services industries, and then also look at differences according to the nationality of foreign ownership. Since the results in column (2) of Table 5 provide us with more statistically significant results, we take 2009 as the crisis period and use this definition of the crisis variable in what follows.

Columns (1) and (2) of Table 6 provide estimates of the hazard model for manufacturing and services industries separately. As the number of observations show, we have three times as many observations for the services sector than for manufacturing, indicating the importance of this sector for the Irish economy.

The estimates for the manufacturing sector show that, once controlling for sectoral characteristics using two digit industry dummy variables, firm-level characteristics explain little of the variation in firm exit. The only statistically significant variable is the crisis dummy, indicating that firm exit increased substantially during the crisis. This is different in the services sector, however, where we find the same results as those obtained in Table 5.

\footnotetext{
${ }^{16}$ This is done using a simple t-test, the probability value of the test is 0.55 .
} 
This shows that the pooled results in Table 5 were mainly driven by the exit behaviour of services firms.

We now look at the size of the coefficients. The betas estimated in the complementary loglog model can be interpreted as the coefficients from a hazard model. Hence, a hazard ratio can be calculated as $\exp \left(\beta_{\mathrm{k}}\right)$ for the $\mathrm{k}^{\text {th }}$ regressor. For example, in column (2) the coefficient on foreign ownership is -0.497 , equivalent to a hazard ratio of $\exp (-0.497)=0.61$. This implies that the hazard of exiting for a foreign firm in the services sector is only 61 percent that of a domestic firm, or equivalently that the hazard is 39 percent lower for foreign than for domestic services firms. This, however, applies only to the time before the crisis. During the crisis, the coefficient for foreign firms is $-0.497+$ 0.483, and we cannot reject the hypothesis that this sum is equal to zero. This indicates that during the crisis, the hazard of exiting is no different for foreign firms compared to domestic firms in the services sector.

This represents, of course, the effect of foreign ownership for an 'average foreign firm'. However, as expected, foreign multinationals in Ireland stem from a multitude of different home countries. Chief among these are the US and the EU (including the UK), but there are also substantial numbers of firms from other countries, including South Africa, South East Asia and Latin America. In order to check whether there are differences in behaviour for firms from different home countries, we group firms into those originating from the EU, North America and the rest of the world (RoW).

Our expectation is to find some differences. Görg, Hanley and Strobl (2011) find that there are no significant differences in the ratio of locally sourced inputs between these (roughly similarly defined) nationality groupings, suggesting that they are similarly shallowly linked into the local economy in terms of input links. This may, firstly, go against the expectation that there may be differences. However, sunk costs play an important role for FDI, and one may expect that sunk costs are quite different for different 
firms. Sunk costs may especially be different due to distance. Compare, for example, the location decision of a British with that of a US firm. While many framework conditions are similar (language, legal system, etc.) the distance for the US firm is much larger and increases set up costs for transport, supervision and communication. This would be even more severe for, e.g., a Japanese firm in Ireland. Given these higher sunk costs, the US or Japanese firm may be less willing to leave during a temporary negative shock than a comparable firm from neighbouring EU countries. ${ }^{17}$

Distinguishing by nationality in this way unearths some interesting results in columns (3) and (4) of Table 6. Firstly, the conclusions do not change for the manufacturing sector: firm characteristics, including nationality of ownership, do not explain much of the variation in hazard rates. In the services sector, however, this is not the case.

From column (2) we know that foreign firms are less likely to leave per se. Column (4), however, shows that this is only the case for multinationals from EU countries. The point estimate suggests that they are 44 percent less likely to exit than their Irish owned counterparts before the crisis. ${ }^{18}$ Foreign firms from other countries, including the US, do not exhibit differences in exit rates compared to domestic firms. More strikingly, however, we find that the performance advantage of EU multinationals evaporates during the crisis. We cannot reject the hypothesis that the coefficients on the EU dummy (-0.575) and the interaction of the EU dummy * crisis (0.639) add up to zero, i.e., during the crisis, EU multinationals are not different compared to Irish owned firms in their exit behaviour.

Hence, during the crisis, all firms are equally likely to leave. This increase in the exit hazard due to the crisis is given by the coefficient on the crisis dummy, which is 0.593 for the services sector, implying an increase in the hazard of exiting for all types of firms in

\footnotetext{
${ }^{17}$ This theoretical argument is based on Dixit's (1989) model on exit under uncertainty. See also Görg (2005) for related empirical evidence on exit costs and FDI.

${ }^{18}$ Calculated as $\exp (-0.575)=0.56 ; 1-0.56=0.44$
} 
the services sector by roughly 80 percent (compared to Irish owned firms before the crisis) during the crisis. In contrast, in the manufacturing sector, the crisis increases the hazard of exiting by about 40 percent (column (2)). ${ }^{19,20}$

\section{(Table 6 here: firm exit by sector)}

\section{CONCLUSIONS AND POLICY IMPLICATIONS}

The Irish Government introduced an Enterprise Stability Fund in 2009 which is administered by the Industrial Development Agency (IDA Ireland). This fund is particularly targeted at companies that encountered difficulties as a result of the crisis in order to assist them by means of financial support to survive and continue operations in Ireland. $^{21}$ In the light of this government activity, what are the implications of our analysis?

Firstly, it is evident that firms were hit by the crisis and that their exit probabilities increased substantially. Firm exit is, however, not by itself necessarily a bad thing. Firm churning is an integral part of the process of restructuring in a competitive economy and leads to “creative destruction” (Schumpeter, 1934) introducing new entrepreneurs and ideas into the economy. While acknowledging this, our finding that the crisis on its own (ceteris paribus) leads to increases in firm exit, suggests that even firms that would not have exited under normal conditions have now done so. From this perspective, government intervention may of useful assistance.

The Irish economy, both in manufacturing and services sectors, is heavily reliant on foreign multinationals. Our analysis shows that, on average, foreign multinationals do not

\footnotetext{
${ }^{19}$ Calculated as $\exp (0.593)=1.81$ and $\exp (0.345)=1.41$

${ }^{20}$ One may argue that the effect of the crisis may be different depending on the exposure to export markets of the sector in which the firm operates. We entertain this hypothesis using data from the Census of Industrial Production, which we use to classify sectors as export intensive or not. We then split the sample and run the regression separately for the two groups of firms. Unfortunately, this export data is only available for manufacturing industries. The results, which are reported in the Appendix, show that the probability of exit increases by more in export oriented manufacturing sectors. However, we still fail to find any differences in exit probabilities depending on nationality of ownership.

${ }^{21}$ See http://newsweaver.co.uk/ibec/e_article001413785.cfm?x=b11,0,w, accessed on 4/4/2011
} 
behave any differently in terms of exit behaviour from comparable Irish firms during the crisis. They do not introduce additional instability into the economy. Hence, there is no reason to suggest that government efforts need to be targeted differently to domestic and foreign-owned firms. 


\section{References}

Agarwal, R. and D. Audretsch (2001), "Does Entry Size Matter? The Impact of the Life Cycle and Technology on Firm Survival”, Journal of Industrial Economics, 49, 1-43.

Alfaro, L. and A. Rodríguez-Clare (2004), "Multinationals and Linkages: an Empirical Investigation”, Economia, 4, 13-69

Barry, F. (2005), "A Note on Transfer Pricing and the R\&D Intensity of Irish Manufacturing”, Research Policy, 34, 673-681.

Barry, F. and Bradley, J. (1997), "FDI and Trade: The Irish Host-Country Experience", Economic Journal, 107, 798-1811.

Dixit, A. (1989), "Entry and exit decisions under uncertainty”, Journal of Political Economy, 97, 620-638.

Doms, M.E. and J. B. Jensen (1998), “Comparing wages, skills, and productivity between domestically and foreign-owned manufacturing establishments in the United States", in R. Baldwin, R. Lipsey and J.D. Richardson (eds.), Geography and Ownership as Bases for Economic Accounting, (Chicago: Chicago University Press), 235-255.

Driffield, N., and A. Mohd Noor (1999), "Foreign Direct Investment and Local Input Linkages in Malaysia”, Transnational Corporations, 8, 1-23.

Dunne, P. and Hughes, A. (1994), “Age, Size, Growth and Survival: UK Companies in the 1980s”, Journal of Industrial Economics, 42, 115-140.

FDI Intelligence (2010), "Ireland Suffers Sharp Fall in Inward Investment in 2009 Though Still Punches Above Weight”, available at www.nationalirishbank.ie/PDF/About-theBank/Foreign-Direct-Investment/NIB-fDi-Investment-Performance-Monitor-2009-Feb2010.pdf

Girma, S. and H. Görg (2007), "Multinationals' productivity advantage: Scale or technology?”, Economic Inquiry, 45, 350-362

Görg, H. (2005), “Fancy a Stay at the 'Hotel California’? The Role of Easy Entry and Exit for FDI”, Kyklos, 58, 519-535

Görg, H., A. Hanley and E. Strobl (2011), "Creating backward linkages from multinationals: Is there a role for financial incentives?”, Review of International Economics, 19, 245-259

Görg, H. and F. Ruane (2000), "An Analysis of Backward Linkages in the Irish Electronics Sector”, Economic and Social Review, 31, 115-235

Görg, H. and Strobl, E. (2003), “'Footloose’ multinationals?”, The Manchester School, 71, $1-19$. 
Helpman, E., M.J. Melitz and S.R. Yeaple (2004), “Export Versus FDI with Heterogeneous Firms", American Economic Review, 94, 300-316

Jenkins, S.P. (2005), “Survival Analysis”, mimeo, University of Essex

McAleese, D. and Counahan, M. (1979), “'Stickers' or 'Snatchers'? Employment in Multinational Corporations during the Recession", Oxford Bulletin of Economics and Statistics, 41, 345-358.

Ruane, F. and H. Görg (1997), "The impact of foreign direct investment on sectoral adjustment in the Irish economy”, National Institute Economic Review, 60, 76-86

Ruane, F. and A. Ugur (2005), "Labour Productivity and Foreign Direct Investment in Irish Manufacturing Industry - A Decomposition Analysis", Economic and Social Review, 36, 19 $-43$

Schumpeter, J. (1934), The Theory of Economic Development, (Cambridge, MA: Harvard University Press) 


\section{Appendix}

Table A1 Firm exit in manufacturing by export intensity

\begin{tabular}{|l|l|l|l|l|}
\hline & $(1)$ & $(2)$ & $(3)$ & $(4)$ \\
\hline & Export intensive & $\begin{array}{l}\text { Not export } \\
\text { intensive }\end{array}$ & Export intensive & $\begin{array}{l}\text { Not export } \\
\text { intensive }\end{array}$ \\
\hline Foreign & -0.229 & 0.298 & & \\
\hline Average size & $(0.421)$ & $(0.336)$ & & \\
\hline & 0.001 & -0.006 & 0.001 & -0.006 \\
\hline Age & $(0.001)$ & $(0.002)^{* *}$ & $(0.001)$ & $(0.002)^{* *}$ \\
\hline & 0.120 & 0.025 & 0.127 & 0.027 \\
\hline Crisis 2009 & $(0.117)$ & $(0.077)$ & $(0.117)$ & $(0.077)$ \\
\hline & 0.599 & 0.326 & 0.599 & 0.326 \\
\hline Foreign * Crisis & $(0.239) * *$ & $(0.164)^{* *}$ & $(0.239)^{* *}$ & $(0.164)^{* *}$ \\
\hline & 0.493 & 0.656 & & \\
\hline EU & $(0.632)$ & $(0.542)$ & & \\
\hline & & & -0.691 & 0.301 \\
\hline North America & & & $(0.607)$ & $(0.394)$ \\
\hline & & & 0.531 & 0.592 \\
\hline EU * Crisis & & & $(0.605)$ & $(0.589)$ \\
\hline & & & 0.822 & 0.838 \\
\hline NA * Crisis & & & $(0.851)$ & $(0.608)$ \\
\hline & & & -0.230 & 0.089 \\
\hline Observations & 5595 & 11683 & $(1.179)$ & $(1.166)$ \\
\hline Standar) & 5595 & 11618 \\
\hline
\end{tabular}

Standard errors in parentheses

* significant at $10 \%$; ** significant at $5 \%$; *** significant at $1 \%$

Model includes two digit industry dummies 
Tables

\begin{tabular}{|c|c|c|c|c|c|c|c|c|c|c|}
\hline \multirow[t]{2}{*}{ Table 1} & \multicolumn{10}{|c|}{ Changes in Irish Manufacturing (2008-2009) } \\
\hline & Irish firms & & & & & Foreign firms & & & & \\
\hline & $\begin{array}{l}\text { Number } \\
\text { of plants }\end{array}$ & $\begin{array}{l}\% \\
\Delta\end{array}$ & $\begin{array}{l}\text { Number } \\
\text { employed }\end{array}$ & $\begin{array}{l}\% \\
\Delta\end{array}$ & Output & $\begin{array}{l}\text { Number of } \\
\text { plants }^{1}\end{array}$ & $\begin{array}{l}\% \\
\Delta\end{array}$ & $\begin{array}{l}\text { Number } \\
\text { employed }\end{array}$ & $\begin{array}{l}\% \\
\Delta\end{array}$ & Output \\
\hline 2008 & 4677 & & 103607 & & & 506 & & 92190 & & \\
\hline 2009 & 4046 & -13 & & -11 & 22 & & -16 & & -10 & 80 \\
\hline
\end{tabular}

Notes: Output and wages in Billion Euros. Author calculations from Census of Industrial Production (CIP) annual survey: Central Statistics Office, Ireland

${ }^{1}$ Local units in NACE Rev.2 reported for 2008. Enterprises, not local units, surveyed in 2009.

\begin{tabular}{|c|c|c|c|c|c|c|c|c|c|}
\hline \multirow[t]{3}{*}{ Table 2} & \multicolumn{9}{|c|}{ Manufacturing employment by two digit sector, 2000 and 2007} \\
\hline & \multirow{2}{*}{$\begin{array}{l}\text { NACE } \\
\text { (Rev 2) }\end{array}$} & \multicolumn{4}{|c|}{2000} & \multicolumn{4}{|c|}{2007} \\
\hline & & \multicolumn{2}{|c|}{ foreign } & \multicolumn{2}{|c|}{ Irish } & \multicolumn{2}{|c|}{ foreign } & \multicolumn{2}{|c|}{ Irish } \\
\hline & & & & 13279 & 100 & 10243 & 100 & 12030 & 100 \\
\hline total manufacturing & $15-37$ & 122852 & $100 \%$ & 2 & $\%$ & 9 & $\%$ & 2 & $\%$ \\
\hline food products and beverages & $151-158$ & 7908 & $6 \%$ & 33138 & $25 \%$ & 6381 & $6 \%$ & 32116 & $27 \%$ \\
\hline Textiles & 17 & 2311 & $2 \%$ & 3610 & $3 \%$ & 912 & $1 \%$ & 1983 & $2 \%$ \\
\hline furniture & 20 & 1111 & $1 \%$ & 5138 & $4 \%$ & 662 & $1 \%$ & 6898 & $6 \%$ \\
\hline paper \& paper products & 21 & 898 & $1 \%$ & 4030 & $3 \%$ & 810 & $1 \%$ & 2408 & $2 \%$ \\
\hline media & 22 & 6559 & $5 \%$ & 12329 & $9 \%$ & 5069 & $5 \%$ & 10401 & $9 \%$ \\
\hline chemicals \& chemical products & 24 & 17874 & $15 \%$ & 5324 & $4 \%$ & 19210 & $19 \%$ & 4817 & $4 \%$ \\
\hline rubber \& plastic products & 25 & 3951 & $3 \%$ & 6895 & $5 \%$ & 3061 & $3 \%$ & 6705 & $6 \%$ \\
\hline other non-metallic mineral products & 26 & 1584 & $1 \%$ & 9582 & $7 \%$ & 1636 & $2 \%$ & 10227 & $9 \%$ \\
\hline metals and fabricated metal products & $27-28$ & 3554 & $3 \%$ & 13330 & $10 \%$ & 2336 & $2 \%$ & 14990 & $12 \%$ \\
\hline machinery \& equipment n.e.c & 29 & 6436 & $5 \%$ & 7960 & $6 \%$ & 5596 & $5 \%$ & 6787 & $6 \%$ \\
\hline machinery & 30 & 18303 & $15 \%$ & 2420 & $2 \%$ & 11563 & $11 \%$ & 937 & $1 \%$ \\
\hline electrical mach. \& apparatus n.e.c. & 31 & 9438 & $8 \%$ & 5703 & $4 \%$ & 4502 & $4 \%$ & 3106 & $3 \%$ \\
\hline radio, TV, ICT, Instrumentation & $32-33$ & 28120 & $23 \%$ & 4983 & $4 \%$ & 29734 & $29 \%$ & 3917 & $3 \%$ \\
\hline transport equipment & 34-35 & 5365 & $4 \%$ & 4245 & $3 \%$ & 5519 & $5 \%$ & 2067 & $2 \%$ \\
\hline other miscellaneous manufacturing & $\begin{array}{l}36-37,16,18,19 \\
23,159\end{array}$ & 9440 & $8 \%$ & 14105 & $11 \%$ & 5448 & $5 \%$ & 12943 & $11 \%$ \\
\hline $\begin{array}{l}\text { Notes: Based on own calculatior } \\
\text { years }\end{array}$ & tha 0 & rod & $\mathrm{r}$ & . & $\mathrm{d} h$ & niz & $c_{0}$ & $\mathrm{a}$ & \\
\hline
\end{tabular}


Table 3 Summary statistics for Irish and Foreign owned manufacturing firms: Firmlevel Data

\begin{tabular}{|l|l|l|l|l|}
\hline & \multicolumn{2}{|l|}{$\begin{array}{l}\text { Surviving firms } \\
\text { Irish }\end{array}$} & Failing firms & Irish \\
& & & & \\
2005 & 22,428 & 1,727 & & \\
2006 & 22,118 & 1,708 & 310 & 19 \\
2007 & 21,719 & 1,682 & 399 & 26 \\
2008 & 20,979 & 1,643 & 740 & 39 \\
2009 & 20,348 & 1,584 & 631 & 59 \\
\hline
\end{tabular}

Note: Foreign firms arefirms in which a foreign entity has the largest shareholding.. Source: Authors' calculations based on Amadeus data (Bureau van Dijk). All surveyed firms excluding public utilities

Table 4 Irish and Foreign Firm Exit Rates and Bivariate Measures of Association: Firm-level Data

\begin{tabular}{|l|l|l|l|l|}
\hline & $\begin{array}{l}\text { Exit rates (\%) } \\
\text { Irish }\end{array}$ & $\begin{array}{l}\text { Foreign } \\
1.10(19 / 1,727)\end{array}$ & 0.9493 & Pr Pearson chi $^{2}$ \\
2006 & $1.38(310 / 22,428)$ & $1.5(26 / 1,708)$ & 0.7182 & 0.330 \\
& $1.8(399 / 22,118)$ & & & 0.397 \\
2008 & $3.41(740 / 21,719)$ & $2.32(39 / 1,682)$ & 5.7475 & $0.017 * *$ \\
2009 & $3.01(631 / 20,979)$ & $3.59(59 / 1,643)$ & 1.7526 & 0.186 \\
\hline
\end{tabular}

Note: Foreign firms are firms which are directly or indirectly foreign owned in one of the periods. Source: Authors' calculations based on Amadeus data (Bureau van Dijk). All surveyed firms excluding public utilities 
Table $5 \quad$ Firm exit, all firms

\begin{tabular}{|l|l|l|}
\hline & $(1)$ & $(2)$ \\
\hline & Crisis from 2008 & Crisis from 2009 \\
\hline Foreign & -0.274 & -0.299 \\
\hline Average size & $(0.196)$ & $(0.141)^{* *}$ \\
\hline & -0.001 & -0.001 \\
\hline Age & $(0.001)^{*}$ & $(0.001)^{*}$ \\
\hline & -0.091 & -0.091 \\
\hline Crisis & $(0.025)^{* * *}$ & $(0.025)^{* * *}$ \\
\hline & 1.090 & 0.539 \\
\hline Foreign * Crisis & $(0.052)^{* * *}$ & $(0.055)^{* * *}$ \\
\hline & 0.160 & 0.406 \\
\hline Observations & $(0.234)$ & $(0.224)^{*}$ \\
\hline
\end{tabular}

Standard errors in parentheses

* significant at $10 \%$; ** significant at $5 \%$; *** significant at $1 \%$

Model includes two digit industry dummies

Table $6 \quad$ Firm exit, by sector

\begin{tabular}{|c|c|c|c|c|}
\hline & (1) & $(2)$ & (3) & (4) \\
\hline & Manufacturing & Services & Manufacturing & Services \\
\hline \multirow[t]{2}{*}{ Foreign } & 0.077 & -0.497 & & \\
\hline & $(0.228)$ & $(0.181)^{* * *}$ & & \\
\hline \multirow[t]{2}{*}{ Average size } & -0.002 & -0.001 & -0.002 & -0.001 \\
\hline & $(0.001)$ & $(0.001)$ & $(0.001)$ & $(0.001)$ \\
\hline \multirow[t]{2}{*}{ Age } & 0.025 & -0.122 & 0.025 & -0.122 \\
\hline & $(0.056)$ & $(0.029)^{* * *}$ & $(0.056)$ & $(0.029)^{* * *}$ \\
\hline \multirow[t]{2}{*}{ Crisis 2009} & 0.345 & 0.593 & 0.345 & 0.593 \\
\hline & $(0.122)^{* * *}$ & $(0.062)^{* * *}$ & $(0.122)^{* * *}$ & $(0.062) * * *$ \\
\hline \multirow[t]{2}{*}{ Foreign $*$ Crisis } & 0.380 & 0.483 & & \\
\hline & $(0.386)$ & $(0.279)^{*}$ & & \\
\hline \multirow[t]{2}{*}{ EU } & & & -0.098 & -0.575 \\
\hline & & & $(0.292)$ & $(0.218)^{* * *}$ \\
\hline \multirow[t]{2}{*}{ North America } & & & 0.385 & -0.942 \\
\hline & & & $(0.390)$ & $(0.581)$ \\
\hline \multirow[t]{2}{*}{ RoW } & & & 0.323 & 0.066 \\
\hline & & & $(0.590)$ & $(0.358)$ \\
\hline \multirow[t]{2}{*}{ EU * Crisis } & & & 0.630 & 0.639 \\
\hline & & & $(0.466)$ & $(0.324)^{* *}$ \\
\hline \multirow[t]{2}{*}{ NA * Crisis } & & & -0.117 & 1.127 \\
\hline & & & $(0.811)$ & $(0.766)$ \\
\hline \multirow[t]{2}{*}{ RoW $*$ Crisis } & & & -0.009 & -1.205 \\
\hline & & & $(1.161)$ & (1.063) \\
\hline Observations & 20987 & 61819 & 20987 & 61819 \\
\hline
\end{tabular}

Standard errors in parentheses

* significant at $10 \%$; ** significant at $5 \%$; *** significant at $1 \%$

Model includes two digit industry dummies 